\title{
Effects of positive end expiratory pressure on regional ventilation-perfusion matching and respiratory mechanics: a clinical study
}

\author{
T Mauri $^{1}$, N Eronia ${ }^{2}$, Turrini ${ }^{1,3^{*}}$, BC Cambiaghi ${ }^{2}$, A Benini ${ }^{2}$, G Bellani ${ }^{2}$, A Pesenti $^{2}$ \\ From ESICM LIVES 2015 \\ Berlin, Germany. 3-7 October 2015
}

\section{Introduction}

In intubated acute respiratory failure patients, inhomogeneity of ventilation-perfusion matching (i.e., presence of over-ventilated under-perfused lung regions) might determine extreme $\mathrm{pH}$ shifts and increase the risk of developing ventilator-induced injury. Positive end-expiratory pressure (PEEP) redistributes tidal ventilation towards more perfused dependent lung regions, potentially improving homogeneity of ventilation-perfusion matching.

\section{Objectives}

In this study, we used Electrical Impedance Tomography (EIT) to assess global and regional lung ventilation and perfusion at different PEEP levels and to verify the effects of PEEP on homogeneity of ventilation-perfusion matching.

\section{Methods}

We enrolled 20 intubated critically ill patients undergoing controlled mechanical ventilation, sedated, paralyzed, with $\mathrm{PaO}_{2} / \mathrm{FiO}_{2} \leq 300 \mathrm{mmHg}$ and $\mathrm{PEEP} \geq 5 \mathrm{cmH}_{2} \mathrm{O}$. We randomly applied two PEEP levels (clinical and clinical $+5 \mathrm{cmH}_{2} \mathrm{O}$ ) for 20 minutes each and collected ventilation and EIT data at the end of each step. From EIT, we measured: 1. regional ventilation heterogeneity (VtHet, defined as the ratio between Vt reaching nondependent/dependent lung); 2. regional homogeneity of ventilation-perfusion matching $\left(\mathrm{H}_{\mathrm{V} / \mathrm{P}}\right)$; 3. regional compliance; 4. cumulated regional lung hyperdistension.

\section{Results}

Patients were $62 \pm 12$ years old, $\mathrm{PaO}_{2} / \mathrm{FiO}_{2}$ was $197 \pm$ $52 \mathrm{mmHg}$, lower PEEP was 7 (7-9) $\mathrm{cmH}_{2} \mathrm{O}$ while higher

"IRCCS "Ca' Granda Foundation, Maggiore Policlinico Hospital, Milan, Italy Full list of author information is available at the end of the article
PEEP was $12(12-14) \mathrm{cmH}_{2} \mathrm{O}(\mathrm{p}<0.001)$. At higher PEEP, VtHet was reduced (1.8 (1.5-2.4) vs. 2.2 (1.8-2.6), $\mathrm{p}<0.001)$. Regional $\mathrm{H}_{\mathrm{V} / \mathrm{P}}$ improved at higher PEEP in non-dependent areas $(0.42 \pm 0.24$ vs. $0.29 \pm 0.25, \mathrm{p}<$ $0.01)$ as well as in the dependent ones, albeit non-significantly ( $0.37 \pm 0.20$ vs. $0.33 \pm 0.24, \mathrm{p}=0.196)$ (Figures 1 and 2).

Finally, by applying higher PEEP, regional compliance of non-dependent lung decreased $(31 \pm 12$ vs. $\left.37 \pm 13 \mathrm{~mL} / \mathrm{cmH}_{2} \mathrm{O}, \mathrm{p}<0.001\right)$ and cumulative hyperdistension of the same areas significantly increased $(+18 \pm 7 \%, \mathrm{p}<0.001)$.

\section{Conclusions}

Improved homogeneity of ventilation-perfusion matching might represent one of the protective mechanisms

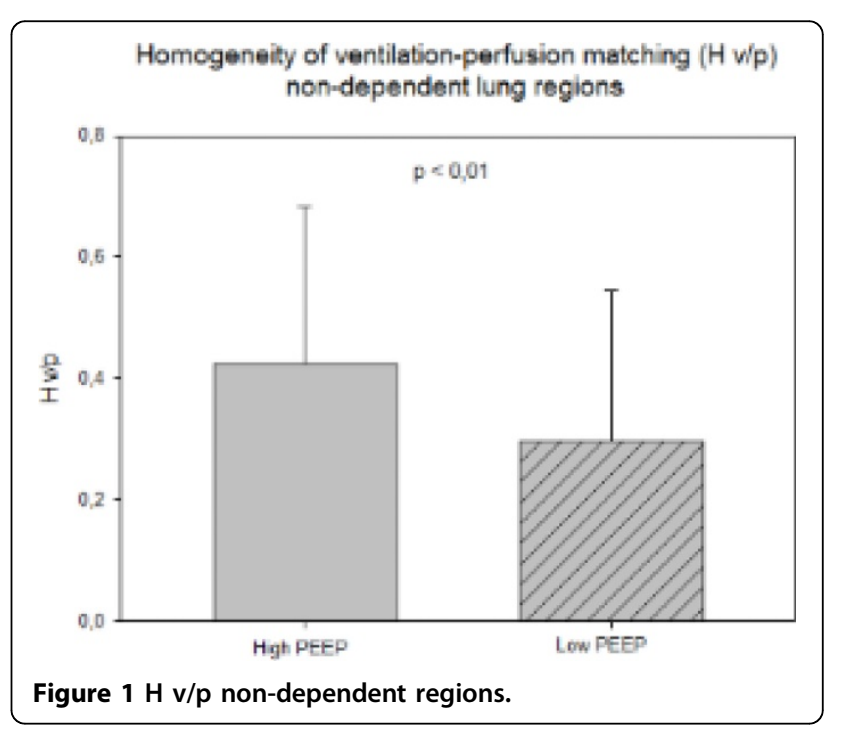

(c) 2015 Eronia et al.; This is an Open Access article distributed under the terms of the Creative Commons Attribution License (http:// creativecommons.org/licenses/by/4.0), which permits unrestricted use, distribution, and reproduction in any medium, provided the original work is properly cited. 


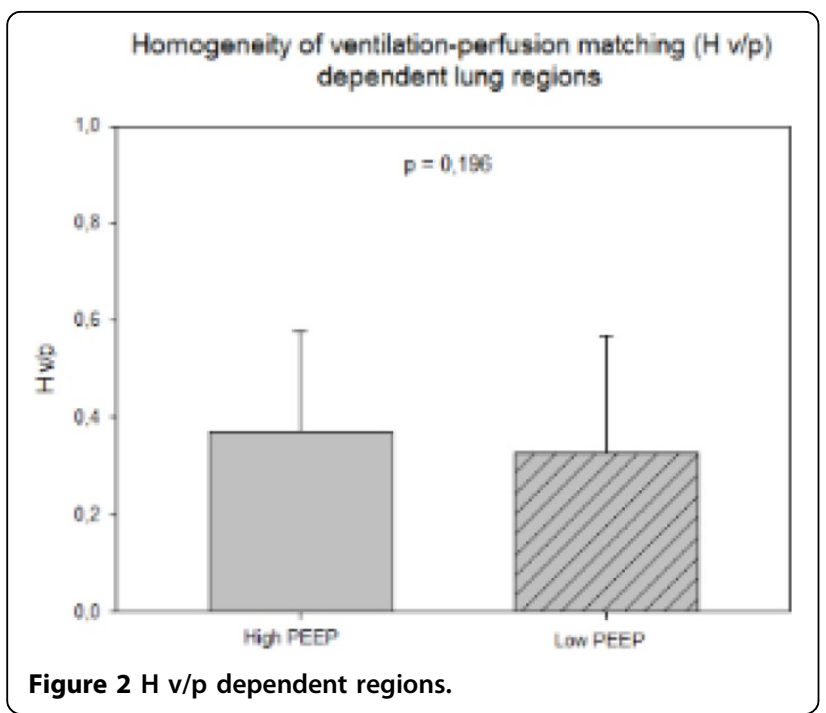

associated with the use of higher PEEP. On the other hand, such benefits must be balanced with increased risk of hyperdistension of non-dependent lung.

\section{Grant Aknowledgement}

Institutional.

\section{Authors' details}

${ }^{1}$ IRCCS "Ca' Granda Foundation, Maggiore Policlinico Hospital, Milan, Italy.

${ }^{2}$ University of Milan-Bicocca, San Gerardo Hospital, Monza, Italy. ${ }^{3}$ University

of Ferrara, Sant'Anna Hospital, Ferrara, Italy.

Published: 1 October 2015

doi:10.1186/2197-425X-3-S1-A8

Cite this article as: Mauri et al:: Effects of positive end expiratory pressure on regional ventilation-perfusion matching and respiratory mechanics: a clinical study. Intensive Care Medicine Experimental 2015

3(Suppl 1):A8.

\section{Submit your manuscript to a SpringerOpen ${ }^{\circ}$ journal and benefit from:}

- Convenient online submission

- Rigorous peer review

- Immediate publication on acceptance

- Open access: articles freely available online

- High visibility within the field

- Retaining the copyright to your article

Submit your next manuscript at $>$ springeropen.com 